\title{
Effect of Sources, Levels and Methods of Potash Fertilization on Yield, Nutrient Uptake, Soil Chemical Properties and Quality of Rabi Onion in an Inceptisol
}

\author{
D.D. Sawale* B. D. Tamboli, Vedshree Patil, A.B. Jadhav, A.L. Pharande and S.K. Bansal \\ Division of Soil Science and Agricultural Chemistry, College of Agriculture, \\ Pune-411005, Maharashtra, India
}

\begin{abstract}
A field experiment on rabi onion ( $c v$. N-2-4-1) was carried out experimental farm of College of Agriculture, Pune during the winter season of 201617 , to study the effect of different levels and sources of potash $(0,50,100$ and $150 \mathrm{~kg}$ $\mathrm{K}_{2} \mathrm{O}$ ha $\left.^{-1}\right)$ and methods of its application as a basal $\left(30 \% \mathrm{~K}_{2} \mathrm{O}\right.$ at the time of transplanting, 40 per cent through fertigation after 30 days of transplanting till initiation of bulb formation and remaining 30 per cent through fertigation after 60 days of transplanting till bulb formation at weekly intervals, respectively). In addition to that one additional treatment of $100 \mathrm{~kg} \mathrm{~K}_{2} \mathrm{O} \mathrm{ha}^{-1}$ was applied in the proportion of $90 \mathrm{~kg} \mathrm{~K}_{2} \mathrm{O}$ through MOP (Muriate of Potash) as a basal application +10 $\mathrm{kg} \mathrm{K}_{2} \mathrm{O}$ through SOP (Sulphate of Potash) as a foliar spray @ 1\% after 60 and 75 days after transplanting for comparing the methods of $\mathrm{K}$ application. The results revealed that the application of $100 \mathrm{~kg} \mathrm{~K}_{2} \mathrm{O} \mathrm{ha}{ }^{-1}\left(90 \mathrm{~kg} \mathrm{~K}_{2} \mathrm{O} \mathrm{ha}{ }^{-1}\right.$ as basal at the time of transplanting through MOP and $10 \mathrm{~kg} \mathrm{~K}_{2} \mathrm{O}$ through two foliar sprays of SOP at 60 and 75 days after transplanting) recorded maximum fresh bulb weight, dry matter yield; higher bulb diameter and uptake of nitrogen, phosphorus, potassium, sulphur, Fe, $\mathrm{Mn}, \mathrm{Zn}$ and $\mathrm{Cu}$ by rabi onion. There was improvement in available N,P,K, S and $\mathrm{Mn}$ content of soil due to application of $150 \mathrm{~kg} \mathrm{~K}_{2} \mathrm{O} \mathrm{ha}^{-1}$ through SOP applied through soil and fertigation over control. The application of $100 \mathrm{~kg} \mathrm{~K}_{2} \mathrm{O} \mathrm{ha}{ }^{-1}$ (SOP) through soil and fertigation or $100 \mathrm{~kg} \mathrm{~K}_{2} \mathrm{O} \mathrm{ha}^{-1}$ was applied in the proportion of $90 \mathrm{~kg} \mathrm{~K}_{2} \mathrm{O}$ through MOP as a basal application + $10 \mathrm{~kg} \mathrm{~K}_{2} \mathrm{O}$ through SOP as a foliar spray @ 1\% after 60 and 75 days of transplanting recorded magnitudely lower mean physiological loss in weight.
\end{abstract}

Keywords: Potash, rabi onion, yield and quality

\section{Introduction}

Onion (Allium cepa L.) is one of the most important vegetable grown all over the world. India is second largest producer of onion next to China. At present, Maharashtra is the largest producer in the country with an output of 12-15 lakh tones production from one lakh hectare area.

The potassium nutrition to onion has important role in storage quality. The application of appropriate

\footnotetext{
*Corresponding author: (Email: ddspune@yahoo.co.in)
}

quantity and source of nutrients to onion at critical growth stage is essential for better growth and quality (Kale et al. 1992). Potash nutrition has great role to play for regulating respiration, improving the quality parameters, prolonging the shelf life, developing the healthy root system etc. It is observed that the doses of $\mathrm{K}$ fertilizers added to vegetable crops are at much lower rate than its removal resulting in a negative balance in soil. Potash requirement for most of the crop is increasing due to intensive agriculture vis-à-vis cultivator's aim at higher yield and quality produce of 
crops per unit area and per unit time. The limited use of organic manures and relatively minimum use of fertilizer potassium lead to widespread deficiency of K in cultivated soils.

Moreover, different sources like MOP and SOP may also have bearing on yield and quality of onion as $\mathrm{S}$ applied through SOP is thought to have positively affect on onion yield and quality. Scarcity of water has lead to use of micro irrigation methods and also $\mathrm{K}$ fertilizer application through fertigation and foliar application is also supposed to enhance the efficiency of both water uses as well as of the $\mathrm{K}$ applied. The present experiment aims to evaluate the sources levels and methods of $\mathrm{K}$ application productivity and quality rabi onion.

\section{Material and Methods}

A field experiment was conducted at experimental Farm, College of Agriculture, and Pune (M.S.) in 2016-17 to study the influence of different sources, levels and methods of application of potash on yield and nutrient uptake of rabi onion ( $c v$. N-2-4-1). The soil (Vertic Haplustepts) had $56.25 \%$ clay with $\mathrm{pH}$ 8.17, electrical conductivity (EC) $0.13 \mathrm{dSm}^{-1}$, organic carbon $\left(6.8 \mathrm{~g} \mathrm{~kg}^{-1}\right)$, calcium carbonate $\left(27.50 \mathrm{~g} \mathrm{~kg}^{-1}\right)$, low in available nitrogen $\left(147 \mathrm{~kg} \mathrm{ha}^{-1}\right)$, medium in available phosphorus (19.8 $\left.\mathrm{kg} \mathrm{ha}^{-1}\right)$ and very high in available potassium (304 kg ha ${ }^{-1}$ ). There were 8 treatments replicated thrice in a randomized block design with plot size 15 sq.m. $\left(5.0 \times 3.0 \mathrm{~m}^{2}\right)$ with row to row spacing $15 \times 10 \mathrm{~cm}$ and plant to plant distance $10.0 \mathrm{~cm}$ on raised bed. The treatments namely, $\mathrm{T}_{1}$-. control (only application of $\mathrm{N}$ and $\mathrm{P}_{2} \mathrm{O}_{5}$ but no application of $\mathrm{K}_{2} \mathrm{O}$ ); for $\mathrm{T}_{2}, \mathrm{~T}_{3}$ and $\mathrm{T}_{4}$ had $\mathrm{K}_{2} \mathrm{O}$ through muriate of potash (MOP) @ 50, 100 and $150 \mathrm{~kg} \mathrm{ha}^{-1}$ respectively; for $\mathrm{T}_{5}, \mathrm{~T}_{6}$ and $\mathrm{T}_{7}$, $\mathrm{K}_{2} \mathrm{O}$ was applied through sulphate of potash (SOP) @ 50,100 and $150 \mathrm{~kg} \mathrm{ha}^{-1}$ respectively through soil and fertigation (The $\mathrm{K}_{2} \mathrm{O}$ through MOP and SOP applied @ $30 \% \mathrm{~K}_{2} \mathrm{O}$ at the time of transplanting, $40 \% \mathrm{~K}_{2} \mathrm{O}$ through fertigation from first leaf fall (after 30 DAT) till initiation of bulb formation at weekly intervals and remaining $30 \% \mathrm{~K}_{2} \mathrm{O}$ through fertigation at initiation of bulb formation (after 60 DAT) till bulb formation at weekly intervals for $T_{2}$ to $T_{4}$ and $T_{5}$ to $T_{7}$ treatments respectively) and $\mathrm{T}_{8}-100 \mathrm{~kg} \mathrm{~K} 2 \mathrm{O}$ applied through both MOP as a basal and SOP $\left(90 \% \mathrm{~K}_{2} \mathrm{O}\right.$ i.e. $90 \mathrm{~kg} \mathrm{~K}_{2} \mathrm{O} \mathrm{ha}^{-1}$ as a basal at the time of transplanting through MOP and $10 \% \mathrm{~K}_{2} \mathrm{O}$ i.e. $10 \mathrm{~kg} \mathrm{~K}_{2} \mathrm{O} \mathrm{ha}^{-1}$ was applied in two foliar sprays through SOP at 60 and 75 days DAT @ 1\% $\mathrm{K}_{2} \mathrm{O}$ i.e. $10 \mathrm{~kg} \mathrm{~K}_{2} \mathrm{O} \mathrm{ha}^{-1}$ through SOP at 60 and 75 days after transplanting). The recommended dose of $100 \mathrm{~kg} \mathrm{~N}$ (50 $\% \mathrm{~N}$ at transplanting and remaining $50 \% \mathrm{~N}$ after 30 days of transplanting) and entire $50 \mathrm{~kg} \mathrm{P}_{2} \mathrm{O}_{5}$ ha $^{-1}$ through DAP along with $20 \mathrm{tha}^{-1} \mathrm{FYM}$ and bio-fertilizers was applied in all the treatments as a basal application. All recommended package of practices were adopted while raising the crop.

At harvest, random sample of five plants were selected from each plot and plant height $(\mathrm{cm})$ and neck thickness $(\mathrm{cm})$ at 90 DAT, number of leaves per plant at 60 and 90 DAT were recorded. Agronomic yield was computed on plot basis and then converted into per hectare basis. Plant samples were dried to a constant weight, processed and analyzed. Total $\mathrm{N}$ was determined using the micro-kjeldhal digestion method with 1:1 $\mathrm{H}_{2} \mathrm{SO}_{4}: \mathrm{H}_{2} \mathrm{O}_{2}$ (Parkinson and Allen 1975) followed by ammonia estimation. Total $\mathrm{P}, \mathrm{K}$ and micronutrient cations were determined following wet digestion of the dried plant material with 4:10 $\mathrm{HNO}_{3}$ : $\mathrm{HClO}_{4}$ (Johnson and Ulrich 1959). The data on various parameters recorded during the period of investigation were tabulated and statistically analyzed (Panse and Sukhatme 1967).

\section{Results and Discussion}

\section{Yield contributing characters}

The results revealed that number of leaves at 60 and 90 DAT, plant height at 90 DAT and neck thickness at 90 DAT did not have significant differences for different treatments (Table 1). However, the application of $100 \mathrm{~kg} \mathrm{~K}_{2} \mathrm{O} \mathrm{ha}^{-1}\left(90 \mathrm{~kg} \mathrm{~K}_{2} \mathrm{O} \mathrm{ha}^{-1}\right.$ as basal at the time of transplanting through MOP and $10 \mathrm{~kg} \mathrm{~K}_{2} \mathrm{O}$ through two foliar sprays of SOP at 60 and 75 days after transplanting) recorded significantly higher bulb diameter $(6.89 \mathrm{~cm})$ owing to diameter may be attributed potassium and sulphate nutrition which might have enhanced the photosynthetic activity and enzymes of carbohydrates transformation. Similar results were also reported by El-Tohamy et al. (2011) in carrot crop. 
Sawale et al.

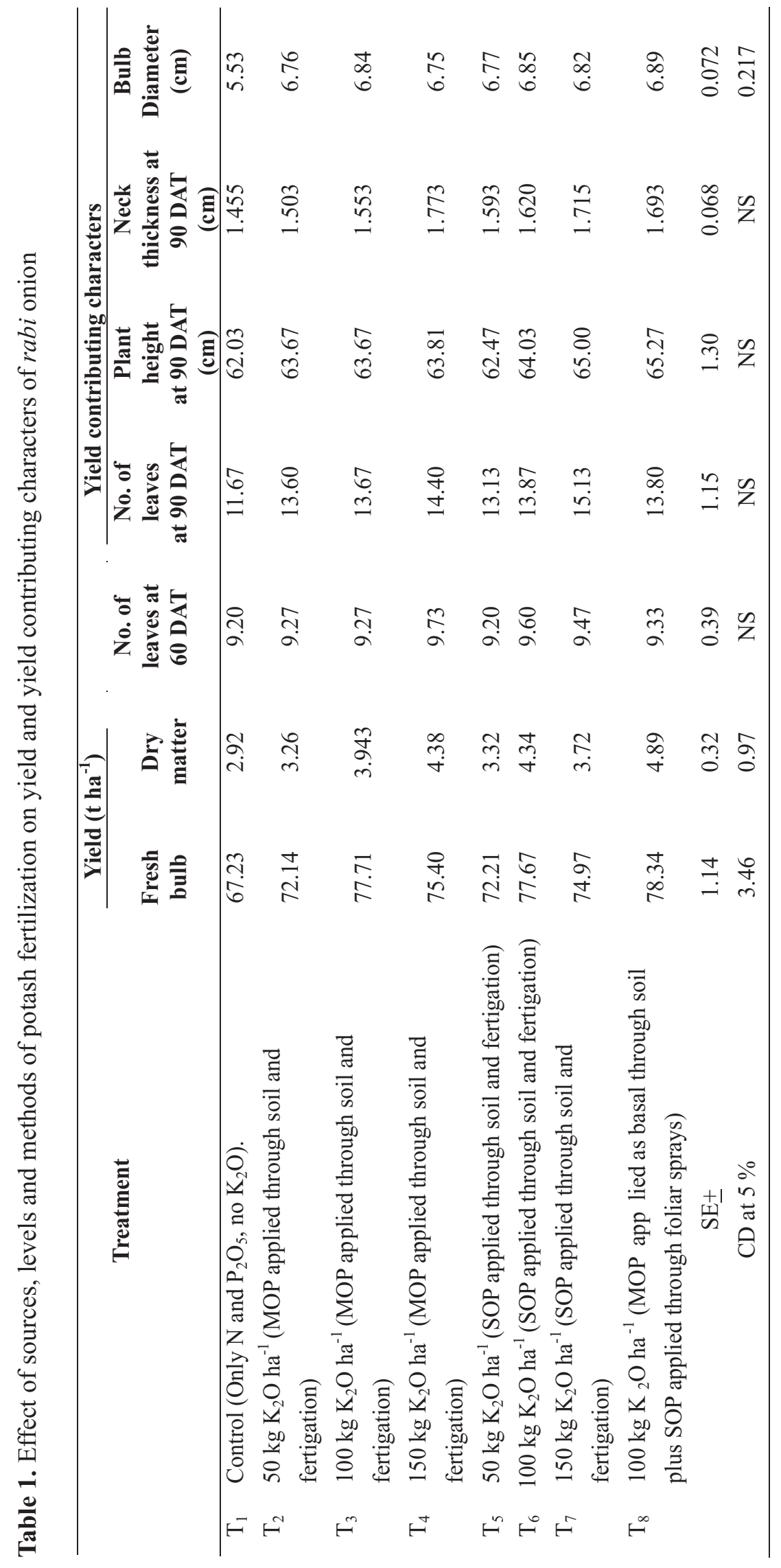


Yield

The data (Table 1) showed that potassium application through soil, fertigation and foliar through different sources had a significant effect on bulb yield. The application of $100 \mathrm{~kg} \mathrm{~K}_{2} \mathrm{O} \mathrm{ha}^{-1}\left(\mathrm{~T}_{8}-90 \mathrm{~kg} \mathrm{~K}_{2} \mathrm{O} \mathrm{ha}^{-1}\right.$ as basal at the time of transplanting through MOP and $10 \mathrm{~kg}$ $\mathrm{K}_{2} \mathrm{O}$ through two foliar sprays of SOP at 60 and 75 days after transplanting) recorded maximum fresh bulb weight (78.34 tha $\left.\mathrm{th}^{-1}\right)$ and dry matter yield $\left(4.89 \mathrm{tha}^{-1}\right)$ and closely followed by $100 \mathrm{~kg} \mathrm{~K}_{2} \mathrm{O}$ through MOP and SOP applied through soil and fertigation. However, these treatments were on par with $150 \mathrm{~kg} \mathrm{~K}_{2} \mathrm{O}$ ha $^{-1}$ application either through MOP or SOP. Similar trend was also noticed for dry matter yield. The higher bulb yield might be attributed to the vigour of plant growth due to potassium via its influence on metabolism of plant enzymes and photosynthesis. Similar results was also reported by Ali et al. (2007). As the K level increases up to optimum level, the yield and its related parameters also increased (Pervez et al. 2004).

\section{Nutrient uptake}

Macronutrients

The application of $100 \mathrm{~kg} \mathrm{~K}_{2} \mathrm{O} \mathrm{ha}^{-1}\left(\mathrm{~T}_{6}-90 \mathrm{~kg}\right.$ $\mathrm{K}_{2} \mathrm{O}$ ha $^{-1}$ as basal at the time of transplanting through MOP and $10 \mathrm{~kg} \mathrm{~K}_{2} \mathrm{O}$ through two foliar sprays of SOP at
60 and 75 days after transplanting) recorded significantly higher nitrogen (180.27 kg ha-1), phosphorus (103.4 $\left.\mathrm{kg} \mathrm{ha}^{-1}\right)$, potassium (259.40 kg ha-1) and sulphur ( $\left.97.68 \mathrm{~kg} \mathrm{ha}^{-1}\right)$ uptakes. However in case of potassium and sulphur uptake, treatment $\mathrm{T}_{6}$ was significantly superior over rest of the treatment. The lowest $\mathrm{N}, \mathrm{P}, \mathrm{K}$ and $\mathrm{S}$ uptake was recorded in control treatment (Table 2). The increase in N, P, K and sulphur uptakes may be ascribed to the role of potassium photosynthetic activities resulting high translocation of assimilates in from leaves to the bulbs (Behairy et al. 2015).

\section{Micronutrients}

The uptake of Fe (3404 $\left.\mathrm{g} \mathrm{ha}^{-1}\right), \mathrm{Mn}$ (873 $\left.\mathrm{g} \mathrm{ha}^{-1}\right), \mathrm{Zn}\left(1084 \mathrm{~g} \mathrm{ha}^{-1}\right)$ and $\mathrm{Cu}\left(386 \mathrm{~g} \mathrm{ha}^{-1}\right)$ by rabi onion was significantly higher due to $\mathrm{T}_{8}$ treatment $\left(90 \mathrm{~kg} \mathrm{~K}_{2} \mathrm{O}\right.$ $\mathrm{ha}^{-1}$ as basal at the time of transplanting through MOP and $10 \mathrm{~kg} \mathrm{~K}_{2} \mathrm{O}$ through two foliar sprays of SOP at 60 and 75 days after transplanting). The lower Fe, Mn, Zn and $\mathrm{Cu}$ uptake was recorded in control (Table 2). The increased uptake of Fe, $\mathrm{Mn}, \mathrm{Zn}$, and $\mathrm{Cu}$ may be due to the role of potassium in plant metabolism and many important regulatory processes in the plant. Potassium and sulphur could increase mineral uptake by the plants (Marschner 1995). 
Table 2. Effect of sources, levels and methods of potash fertilization on total macronutrient and micronutrient uptake by rabi onion at harvest

\begin{tabular}{|c|c|c|c|c|c|c|c|c|c|}
\hline & \multirow{2}{*}{ Treatment } & \multicolumn{4}{|c|}{$\begin{array}{c}\text { Macronutrient uptake } \\
\qquad\left(\mathrm{kg} \mathrm{ha}^{-1}\right)\end{array}$} & \multicolumn{4}{|c|}{$\begin{array}{l}\text { Micronutrient uptake } \\
\qquad\left(\mathrm{g} \mathrm{ha}^{-1}\right)\end{array}$} \\
\hline & & $\mathbf{N}$ & $\mathbf{P}$ & $\mathbf{K}$ & $\mathbf{S}$ & $\mathrm{Fe}$ & Mn & $\mathrm{Zn}$ & $\mathrm{Cu}$ \\
\hline$T_{1}$ & $\begin{array}{l}\text { Control (Only } \mathrm{N} \text { and } \mathrm{P}_{2} \mathrm{O}_{5} \text {, no } \\
\mathrm{K}_{2} \mathrm{O} \text { ). }\end{array}$ & 127.72 & 64.63 & 155.52 & 60.09 & 2397 & 548 & 717 & 211 \\
\hline $\mathbf{T}_{2}$ & $\begin{array}{l}50 \mathrm{~kg} \mathrm{~K}_{2} \mathrm{O} \mathrm{ha}^{-1} \text { (MOP applied } \\
\text { through soil and fertigation) }\end{array}$ & 140.72 & 75.87 & 176.78 & 70.81 & 2660 & 647 & 823 & 250 \\
\hline $\mathbf{T}_{3}$ & $\begin{array}{l}100 \mathrm{~kg} \mathrm{~K}_{2} \mathrm{O} \mathrm{ha}^{-1} \text { (MOP applied } \\
\text { through soil and fertigation) }\end{array}$ & 166.53 & 89.97 & 222.91 & 83.79 & 3054 & 749 & 956 & 312 \\
\hline $\mathbf{T}_{4}$ & $\begin{array}{l}150 \mathrm{~kg} \mathrm{~K}_{2} \mathrm{O} \mathrm{ha}^{-1} \text { (MOP applied } \\
\text { through soil and fertigation) }\end{array}$ & 166.41 & 92.70 & 234.60 & 87.39 & 3228 & 804 & 1012 & 339 \\
\hline $\mathbf{T}_{5}$ & $\begin{array}{l}50 \mathrm{~kg} \mathrm{~K}_{2} \mathrm{O} \mathrm{ha}^{-1} \text { (SOP applied } \\
\text { through soil and fertigation) }\end{array}$ & 142.41 & 78.86 & 183.50 & 73.86 & 2713 & 618 & 849 & 272 \\
\hline $\mathbf{T}_{6}$ & $\begin{array}{l}100 \mathrm{~kg} \mathrm{~K}_{2} \mathrm{O} \mathrm{ha}^{-1} \text { (SOP applied } \\
\text { through soil and fertigation) }\end{array}$ & 172.07 & 93.28 & 235.65 & 87.64 & 3179 & 786 & 1013 & 333 \\
\hline $\mathbf{T}_{7}$ & $\begin{array}{l}150 \mathrm{~kg} \mathrm{~K}_{2} \mathrm{O} \mathrm{ha}^{-1} \text { (SOP applied } \\
\text { through soil and fertigation) }\end{array}$ & 161.98 & 92.50 & 227.82 & 87.25 & 3029 & 756 & 973 & 333 \\
\hline $\mathbf{T}_{8}$ & $\begin{array}{l}100 \mathrm{~kg} \mathrm{~K}_{2} \mathrm{O} \text { ha }{ }^{-1} \text { (MOP } \\
\text { applied as basal through soil } \\
\text { plus SOP applied through } \\
\text { foliar sprays) }\end{array}$ & 180.27 & 103.40 & 259.40 & 97.68 & 3404 & 873 & 1084 & 386 \\
\hline & $\mathrm{SE} \pm$ & 5.94 & 3.59 & 5.14 & 2.86 & 110.0 & 27.2 & 38.5 & 14.5 \\
\hline & $\mathrm{CD}$ at $5 \%$ & 18.03 & 10.89 & 15.60 & 8.68 & 333.8 & 82.5 & 116.7 & 44.0 \\
\hline
\end{tabular}

\section{Soil chemical properties}

The results indicate that soil $\mathrm{pH}, \mathrm{EC}$, organic carbon and calcium carbonate content of soil were not significantly influenced due to different levels and sources of potash application at harvest. The soil available N,P,K,S content of soil increased significantly with increase in levels and sources of potassium. The application of $150 \mathrm{~kg} \mathrm{~K}_{2} \mathrm{O} \mathrm{ha}^{-1} \mathrm{SOP}$ applied through soil and fertigation had maximum available $\mathrm{N}, \mathrm{P}, \mathrm{K}$ and $\mathrm{S}$ (Table 3). The results of present investigation are in conformity with the findings of Kumar et al. (2006) and Singh and Pandey (2006). The DTPA - Fe, Zn and $\mathrm{Cu}$ were not significantly increased due to different 

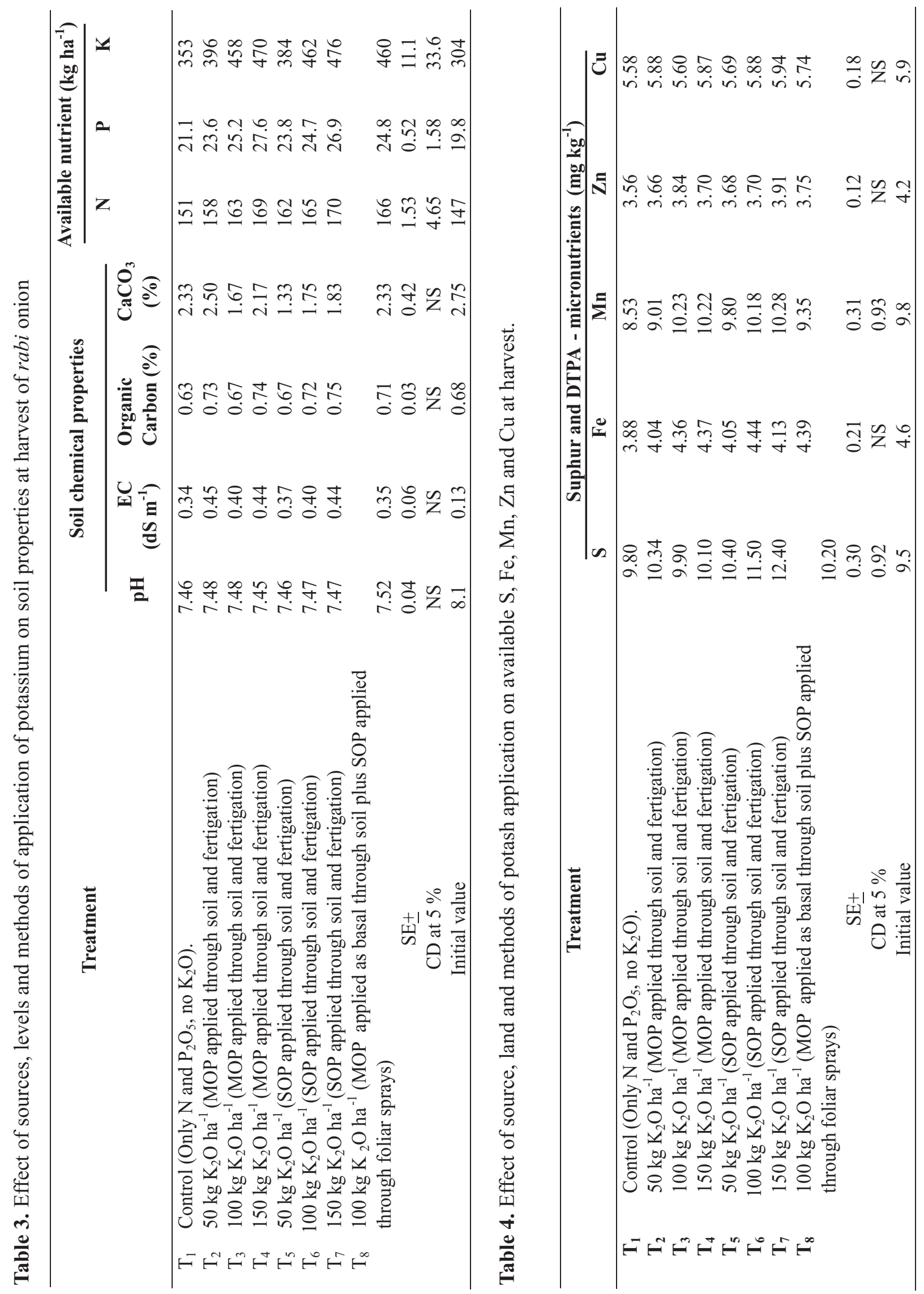
treatments (Table 4). The application of $150 \mathrm{~kg} \mathrm{~K}_{2} \mathrm{O}$ $\mathrm{ha}^{-1}$ through SOP applied through soil and fertigation recorded significantly higher in DTPA - Mn over control.

\section{Bulbquality}

The bulb quality in terms of physiological loss in weight of rabi onion was increased significantly with increase in storage period up to four months (Table 5). The treatment $\mathrm{T}_{6}\left(100 \mathrm{~kg} \mathrm{~K}_{2} \mathrm{O}\right.$ ha $^{-1}$
SOP applied through soil and fertigation) recorded lower mean physiological loss in weight $(8.9 \%)$ which was closely followed by $\mathrm{T}_{8}\left(90 \mathrm{~kg} \mathrm{~K}_{2} \mathrm{O} \mathrm{ha}^{-1}\right.$ as basal at the time of transplanting through MOP and $10 \mathrm{~kg} \mathrm{~K}_{2} \mathrm{O}$ through two foliar sprays of SOP at 60 and 75 days after transplanting). However, the highest physiological loss in mean weight $(15.4 \%)$ was recorded in control treatment. The role of potassium in augmenting yield and improving the quality of onion bulb in term of physiological loss in weight is also reported by Kale et al. (1992).

Table 5. Effect of sources, levels and methods of potash fertilization on periodical mean physiological loss in weight of bulb

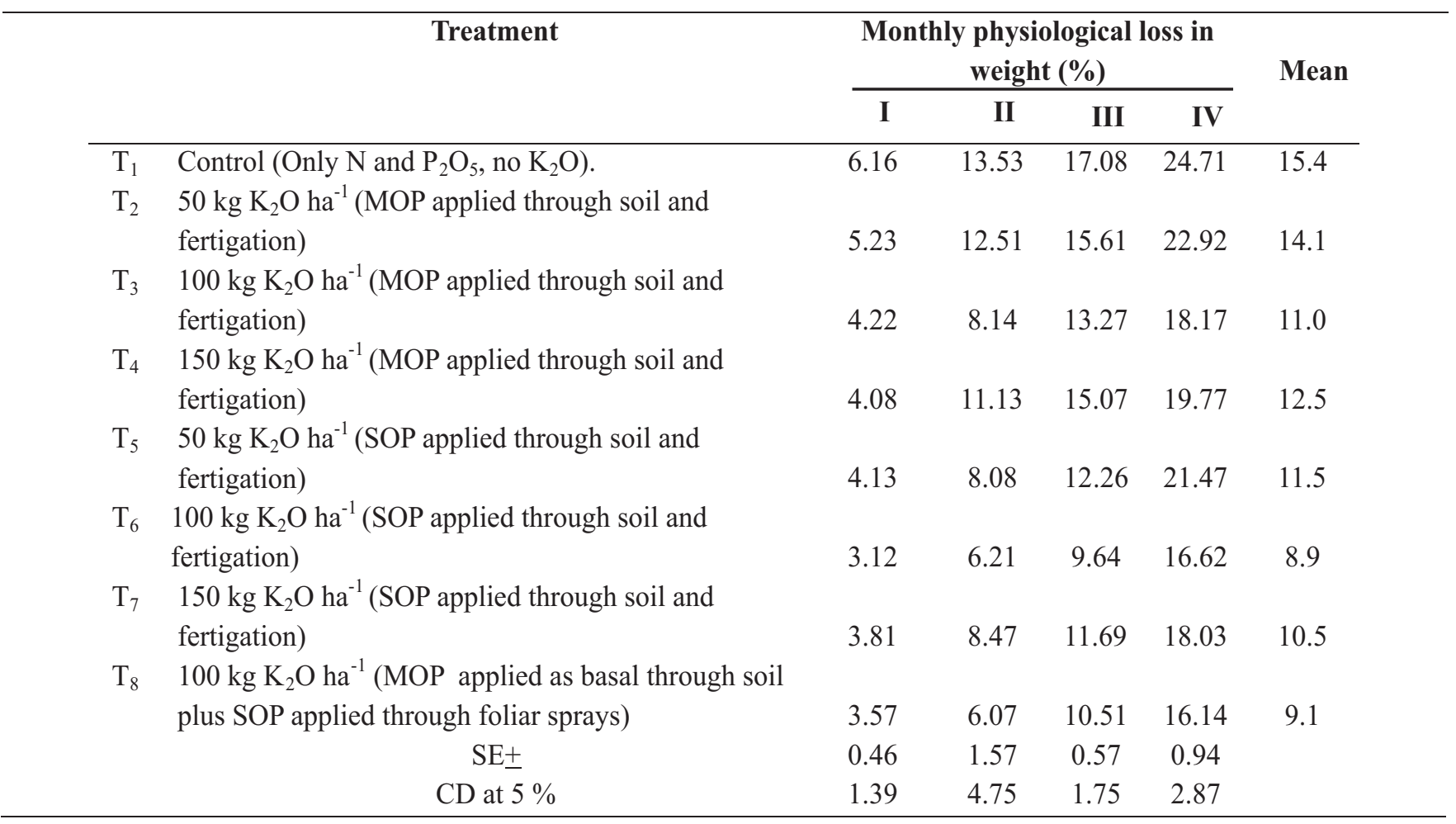

\section{Economics}

The results (Table 6) showed that the application of $100 \mathrm{~kg} \mathrm{~K}_{2} \mathrm{O} \mathrm{ha}^{-1}\left(90 \mathrm{~kg} \mathrm{~K}_{2} \mathrm{O} \mathrm{ha}^{-1}\right.$ as basal at the time of transplanting through $\mathrm{MOP}$ and $10 \mathrm{~kg} \mathrm{~K}_{2} \mathrm{O}$ through two foliar sprays of SOP at 60 and 75 days after transplanting) recorded the highest net returns of Rs. $1,11,100 \mathrm{ha}^{-1}$ over control. The next best treatment was $\mathrm{T}_{3}$ where $100 \mathrm{~kg}$ $\mathrm{K}_{2} \mathrm{O}$ ha $^{-1}$ was applied as MOP through soil and fertigation. 
Table 6. Effect of sources, levels and methods of potash fertilization on economics of potash fertilizer of rabi onion

\begin{tabular}{|c|c|c|c|c|c|c|c|}
\hline \multirow[b]{2}{*}{ Treatment } & \multirow[b]{2}{*}{$\begin{array}{c}\text { Fresh } \\
\text { bulb } \\
\text { Yield } \\
\left(\mathrm{t} \mathrm{ha}^{-1}\right)\end{array}$} & \multirow[b]{2}{*}{$\begin{array}{l}\text { Dry } \\
\text { matter } \\
\text { Yield } \\
\left(\mathrm{t} \mathrm{ha}^{-1}\right)\end{array}$} & \multicolumn{5}{|c|}{ Economics of potash fertilizer } \\
\hline & & & $\begin{array}{c}\text { Cost of } \\
\text { fertilizer } \\
\left(\text { Rs ha }^{-1}\right)\end{array}$ & $\begin{array}{c}\text { Cost of } \\
\text { fertilizer } \\
\text { increase } \\
\text { over } \\
\text { control } \\
\left(\text { Rs ha }^{-1}\right)\end{array}$ & $\begin{array}{c}\text { Gross } \\
\text { monetary } \\
\text { returns } \\
\left(\operatorname{Rs~ha}^{-1}\right)\end{array}$ & $\begin{array}{c}\text { Gross } \\
\text { monetary } \\
\text { returnes } \\
\text { increase } \\
\quad \text { over } \\
\text { control } \\
\left(\text { Rs ha }^{-1}\right)\end{array}$ & $\begin{array}{c}\text { Returns/Rupees } \\
\text { invested on } \\
\text { potash } \\
\text { fertilizers }\end{array}$ \\
\hline $\begin{array}{l}\mathrm{T}_{1} \text { Control (Only } \mathrm{N} \text { and } \\
\left.\mathrm{P}_{2} \mathrm{O}_{5} \text {, no } \mathrm{K}_{2} \mathrm{O}\right)\end{array}$ & 67.23 & 2.92 & 33842 & -- & 672300 & -- & -- \\
\hline $\begin{array}{l}\mathrm{T}_{2} 50 \mathrm{~kg} \mathrm{~K}_{2} \mathrm{O} \mathrm{ha}^{-1} \text { (MOP } \\
\text { applied through soil and } \\
\text { fertigation) }\end{array}$ & 72.14 & 3.26 & 35245 & 1403 & 721400 & 49100 & 34.99 \\
\hline $\begin{array}{l}\mathrm{T}_{3} 100 \mathrm{~kg} \mathrm{~K}_{2} \mathrm{O} \mathrm{ha}^{-1} \text { (MOP } \\
\text { applied through soil and } \\
\text { fertigation) }\end{array}$ & 77.71 & 3.943 & 36648 & 2806 & 777100 & 104800 & 37.34 \\
\hline $\begin{array}{l}\mathrm{T}_{4} 150 \mathrm{~kg} \mathrm{~K}_{2} \mathrm{O} \mathrm{ha}^{-1} \text { (MOP } \\
\text { applied through soil and } \\
\text { fertigation) }\end{array}$ & 75.40 & 4.38 & 38050 & 4208 & 754000 & 81700 & 19.41 \\
\hline $\begin{array}{l}\mathrm{T}_{5} 50 \mathrm{~kg} \mathrm{~K}_{2} \mathrm{O} \mathrm{ha}^{-1} \text { (SOP } \\
\text { applied through soil and } \\
\quad \text { fertigation) }\end{array}$ & 72.21 & 3.32 & 37842 & 4000 & 722100 & 49800 & 12.45 \\
\hline $\begin{array}{l}\mathrm{T}_{6} 100 \mathrm{~kg} \mathrm{~K}_{2} \mathrm{O} \mathrm{ha}^{-1} \text { (SOP } \\
\text { applied through soil and } \\
\text { fertigation) }\end{array}$ & 77.67 & 4.34 & 41842 & 8000 & 776700 & 104400 & 13.05 \\
\hline $\begin{array}{l}\mathrm{T}_{7} 150 \mathrm{~kg} \mathrm{~K}_{2} \mathrm{O} \mathrm{ha}^{-1} \text { (SOP } \\
\text { applied through soil and } \\
\text { fertigation) }\end{array}$ & 74.97 & 3.72 & 45842 & 12000 & 749700 & 77400 & 6.45 \\
\hline $\begin{array}{c}\mathrm{T}_{8} 100 \mathrm{~kg} \mathrm{~K}_{2} \mathrm{O} \mathrm{ha}^{-1} \text { (MOP } \\
\text { applied as basal through } \\
\text { soil plus SOP applied } \\
\text { through foliar sprays) }\end{array}$ & 78.34 & 4.89 & 37167 & 3325 & 783400 & 111100 & 33.41 \\
\hline
\end{tabular}

Rates:

Urea: 6.4 Rs. $\mathrm{kg}^{-1}$, DAP: 25 Rs. $\mathrm{kg}^{-1}$, MOP: 16.8 Rs. $\mathrm{kg}^{-1}$, SOP: 40 Rs. $\mathrm{kg}^{-1}$ and FYM: 1.5 Rs. $\mathrm{kg}^{-1}$ and onion bulb Rs. $10 \mathrm{~kg}^{-1}$.

\section{Conclusion}

From the present experimental data, it is concluded that, the application $90 \mathrm{~kg} \mathrm{~K}_{2} \mathrm{O} \mathrm{ha}^{-1}$ as basal at the time of transplanting through MOP and $10 \mathrm{~kg}$ $\mathrm{K}_{2} \mathrm{O}$ through two foliar sprays of SOP @ 1\% at 60 and 75 days after transplanting was found beneficial for increasing fresh bulb yield, bulb diameter and nutrient uptake.

\section{Acknowledgement}

The study was financially supported by Agriculture \& Environment Research Organization, Sector 22, Gurgaon is gratefully acknowledged. 


\section{References}

Ali, M.K., Alam, M.F., Alam, M.N., Islam, M.S., and Khandaker, S.M.A.T. (2007). Effect of nitrogen and potassium level on yield and quality seed production of onion. Journal of Applied Sciences Research 3, 1889-1899.

Behairy, Awatef, G., Asmaa, R. Mahmoud, Shafeek, M.R., Aisha, H. Ali., and Magda, M. Hafez (2015). Growth, yield and bulb quality of onion plants (Allium cepa L.) as affected by foliar and soil application of potassium. Middle East Journal of Agriculture Research 6, 60-66.

El-Tohamy, W.A., E-Abagy, H.M., Badr, M.A., AbouHussein, S.D., and Helmy, Y.I. (2011). The influence of foliar application of potassium on yield and quality of carrot (Daucus carota L.) plants grown under sandy soil conditions. Australian Journal of Basic and Applied Sciences 5, 171-174.

Johnson, C.M., and Ulrich, A. (1959). Analytical methods for use in plant analysis. California Agricultural Experiment Station Bulletin 766, 25-78.

Kale, P.N., Warade S.D., and Desale, S.B. (1992). Developments of storage structure for onion storage at high temperature. Allium Improvement Newsletter 2, 49-52.
Kumar, S. Sushant, Tiwari, C.P., and Vinay, Singh (2006). Bulb yield and quality of onion as affected by application rates of nitrogen and potassium fertilizers. Agricultural Science Digest 26, 11-14.

Marschner, H. (1995). Functions of mineral nutrients: micronutrients. In: Mineral Nutrition of Higher Plants. $2^{\text {nd }}$ Ed., Academic Press, London, pp. 313-404.

Panse, V.G., and Sukhatme, P.V. (1967). Statistical methods for a agricultural workers. ICAR, New Delhi, $2^{\text {nd }}$ ed. pp. 99.

Parkinson, J.A., and Allen, S.E. (1975). A wet oxidation procedure suitable for the determination of nitrogen and mineral nutrients in biological materials. Communications in Soil Science and Plant Analysis 6, 1-11.

Pervez, H., Ashraf, M., and Makhdum, M.I. (2004). Influence of potassium rates and sources on seed cotton yield and yield components of some elite cotton cultivars. Journal of Plant Nutrition 27, 1295-1317.

Singh, V., and Pandey, M. (2006). Effect of integrated nutrient management on yield of and nutrient uptake by onion and on soil fertility. The Journal of the Indian Society of Soil Science 54, 365-367.

Received: January, 2018 Accepted:June,2018 